\title{
Concern and Externalities Associated with Locating Hemp Production and Processing Facilities
}

\author{
Julie H. Campbell ${ }^{1}$, Adam N. Rabinowitz ${ }^{2}$ and Benjamin L. Campbell ${ }^{3, *}$ (1) \\ ${ }^{1}$ Department of Horticulture, University of Georgia, 325 Hoke Smith Building, Athens, GA, 30602, USA, ${ }^{2}$ Department of \\ Agricultural Economics and Rural Sociology, Auburn University, 209A Comer Hall, Auburn, AL, 36849, USA and \\ ${ }^{3}$ Department of Agricultural and Applied Economics, University of Georgia, 147 Cedar St., GA, 30602, USA \\ *Corresponding author. Email: bencamp@uga.edu
}

\begin{abstract}
The legalization of hemp in the United States (U.S.) has created increased interest from agricultural and non-agricultural entities seeking to establish/expand hemp production and processing. As these entities begin to locate their production and processing operations, there is a potential for nearby residents to have concerns about these efforts. Using an online survey of residents from the southeastern U.S., concern levels and potential externalities associated with hemp production and processing were evaluated. Results show a majority of residents are concerned about hemp production and processing locating nearby with the externalities varying from the potential for illegal activity to environmental concerns.
\end{abstract}

Keywords: Externalities; Hemp production; Hemp regulations

JEL code: Q18

\section{Concern and Externalities Associated with Locating Hemp Production and Processing Facilities}

Hemp production has a long history within the United States (U.S.), dating back to the first commercial cultivation in the 1600s and regulatory burdens that began in the early 1900s. Eventually, this led to its classification as a Schedule I controlled substance (see Malone and Gomez [2019], for a detailed overview). There has been a recent revitalization of interest in hemp production that began at the federal level with the Agricultural Act of 2014 (2014 Farm Bill). This Act authorized hemp production by institutes for higher education and state departments of agriculture. Hemp was then removed from the list of Schedule I drugs with the passage of the Agriculture Improvement Act of 2018 (2018 Farm Bill). These two federal regulatory moves have resulted in state-level legislative and regulatory maneuvering.

Some states, such as Kentucky, have been at the forefront of creating opportunities for production through the legislative authority to produce hemp for agricultural research purposes (Kentucky Senate Bill 50, 2013). After the 2014 Farm Bill was enacted, the Kentucky Department of Agriculture launched a hemp pilot program that authorized growing and processing in the state. Meanwhile, other states have been more conservative in their approach to industrial hemp, such as Georgia where legislation to authorize processing and production did not occur until 2019 in response to the 2018 Farm Bill (Georgia House Bill 213, 2019). The passage of the 2018 Farm Bill has created a rush to establish or expand production and access to markets through increased licensing, planted acreage, processing, and end-user product development throughout the U.S. However, the variability in state legislation and regulations has placed a regulatory impediment on the location of production and processing.

(C) The Author(s) 2020. This is an Open Access article, distributed under the terms of the Creative Commons Attribution licence (http:// creativecommons.org/licenses/by/4.0/), which permits unrestricted re-use, distribution, and reproduction in any medium, provided the original work is properly cited. 
As more states establish production and processing rules and as legal risks from production, transportation, and processing have decreased, significant interest has developed throughout the nation to increase the production of hemp. Licensed hemp acreage across 10 U.S. states has grown from 37,122 acres in 2017 to 82,757 acres in 2018, a 123\% growth rate. Growth in 2019 ballooned by $275 \%$ to an estimated 310,721 acres (Sterns, 2019). Other reports have indicated that 511,442 acres were licensed in 2019 across 34 states, although only an estimate of 230,000 acres were actually planted and 115,000-138,000 acres were expected to be harvested (votehemp.com, 2019). The growth of hemp production does come at a cost of other production, such as the transitioning of ornamental greenhouses in the U.S. for both clone stock and finished plants. One of the largest greenhouse producers in the U.S. is moving from ornamental plant production to hemp production. After the conversion, the greenhouse will have 1.8 million square feet of indoor production in Kentucky and 3.6 million square feet (indoor) and 230 acres (outdoor) of production in Illinois devoted to hemp production (Wright, 2019).

Currently, 24 states have hemp acreage with 45 states having enacted some type of hemp legislation (votehemp.com, 2019). Given this surge in production, researchers are beginning to address/readdress numerous issues that are arising from hemp production. Notably, production (e.g., costs of production and production practices) and consumer (e.g., perceptions and marketing research) related matters are the first steps to understanding profitability for firms. Some initial research has been disseminated, but there are still many more questions that need to be answered. Several hemp enterprise budgets have been released within the past year, including for Tennessee (Cui and Smith, 2019), New York (Hanchar, 2019), Kentucky (Shepherd and Mark, 2019), and Pennsylvania (Roth et al., 2018). With respect to consumer issues, Norwood and Murray (2018) found a third of consumers in their sample viewed hemp and marijuana as the same. Though hemp and marijuana are derived from the cannabis plant, the difference between hemp and marijuana is from the percentage of delta- 9 tetrahydrocannabinol (THC) that the plant contains (Shipman 2019). Federally, the 2018 Farm Bill has defined hemp as delta-9 THC concentration of not more than $0.3 \%$ on a dry weight basis, however, states vary in their definition of legal hemp. This includes delta-9 THC $<0.3 \%$, Total THC (delta-9 THC and THCA $<0.3 \%$, undefined THC type $<0.3 \%$, or no THC present.

Stansbury (2018), Johnson (2018), and Mead (2017) examine the wide variety of products that can be made from hemp. These include fiber uses, such as rope, textiles, and building materials, seed use in food and oil, other extracts, and Cannabidiol (CBD oil) which is often touted for its medicinal properties but has only been approved by the Food and Drug Administration as a prescription drug (EPIDIOLEX ${ }^{\oplus}$ )to treat a single severe form of epilepsy. Production for each use (fiber, seed, and CBD oil) all require different practices and research across the U.S. is underway to better understand the agronomic scope of producing hemp with modern practices and current growing conditions.

While the hemp industry is in its expansion phase, the potential pushback from communities and residents living near proposed hemp operations has not been evaluated. As many producers and cities look to cash in on the increasing demand for hemp and hemp-related products (Buckner, 2018; Vielkind, 2019; Wright, 2019), there seems to be little discussion of potential negative externalities associated with hemp production/processing. For instance, neighbors of hemp production/processing facilities may have concerns about the new venture. Though states have the right to farm laws, their legality and applicability when switching to other crops may lead to hemp production ending up in court before allowing new production. Consideration of potential concerns that may complicate establishing or continuing hemp farming is an essential risk management issue. Failure to consider community concerns is not new, especially with greenhouse production (Driscoll, 2017; Georgieva, 2018). Light pollution is a common argument against greenhouses, causing some cities to take action to eliminate this externality (Ouriel, 2019). The odor is another major externality to agricultural production and one that is a significant issue for hemp production. The smell from hemp fields in Oregon has caused illness and issues among 
producers and the community (Eltouny, 2018; Tornay, 2018). Additionally, increased illegal activity is a potential concern given a number of farms throughout the U.S. have had hemp plants stolen from the field (Cordan, 2019; Heady Vermont, 2018). Even though hemp has been reported to be more environmentally friendly than other field crops during production and processing (Averink, 2015; Smith-Heisters, 2008), there is contradictory evidence about its environmental friendliness (Cherney and Small, 2016). Given these potential externalities, it is essential to understand consumer sentiment toward living near hemp production and processing.

Skodzinski (2017) notes that getting local community and government support is critical when thinking about growing cannabis. Consequently, concerns over hemp operations may manifest as a fear of illegal activity, environmental issues that impact the water, air, soil, or even potential public scrutiny of the area. As such, this research attempts to gain insight toward the concerns of residents throughout the southeastern U.S. The main hypothesis is that there will be concern over hemp production and processing facilities being introduced to a nearby area. This study hypothesizes that demographics and area characteristics play a role in the level of concern. Second, the authors take a cursory look at the type of negative externalities that could be of concern. The negative externalities examined are potential for illegal activity, environmental issues that impact the water and air, and the potential public scrutiny of the community.

\section{Materials and Methods}

An online survey was conducted between March 23, 2019 and May 5, 2019, targeting residents of the southeastern U.S., including Alabama, Florida, Georgia, Kentucky, Louisiana, Mississippi, North Carolina, South Carolina, and Tennessee. The survey was approved by the University of Georgia Institutional Review Board (ID\#STUDY00004769). Toluna, Inc. was contracted with and recruited respondents from their database. A random group of respondents in the Toluna, Inc. database that were 18 years of age or older and resided in one of the targeted states were contacted by Toluna, Inc. via email to request their participation in the survey. Respondents agreeing to participate were directed to the survey. In recruiting respondents, Toluna, Inc. attempted to maintain a representative sample whereby the demographics of the sample were comparable to the demographics of the southeastern U.S. As with any survey mechanism, potential biases may exist. Notably, selection bias could challenge the robustness of the results. For instance, selection bias could be an issue if respondents were selected to participate based on their perceptions about hemp or respondent selection was higher in areas with more anti- or pro-hemp perceptions. In order to minimize the potential for selection bias in the sample, Toluna's selection process of potential respondents from their database was random, except for state quotas and efforts to maintain a representative sample via age, household income, and race. To further mitigate selection bias, respondents agreed to participate in the survey prior to knowing the exact nature of the survey (i.e., that hemp questions would be asked), therefore, potential biases associated with respondents self-selecting into the survey only due to anti- or pro-perceptions about hemp should be minimized.

The survey asked a myriad of questions about hemp (shown in Appendix A), like "Would you have any concerns about living near a farm or production facility that grows/produces the following? Hemp production only, no processing; Hemp processing (e.g., making of productions from hemp)." Respondents marked their concern level on a 0 (no concern) to 100 (extremely concerned) point scale. Respondents indicating any concern for hemp production only were asked a follow-up question, "What concern would you have about living near a farm or production facility that grows hemp?" A list of seven choices was provided, whereby a respondent could mark any number of the seven choices. The list of choices included, public scrutiny, impact on the air, impact on water, impact on the environment, the potential for illegal activities, overall safety, and others. Similarly, a respondent that indicated any level of concern for hemp processing 
was shown the same list of choices and asked to indicate which concern they had with a processing facility. Definitions were not provided on the choices of concern, so how each respondent interpreted these were left to the individual. Choices were left general in nature so that a baseline can be formulated as to the overarching issues causing concern. Future research can focus on the specific areas to better understand the causes of concern in each general area (e.g., for air is its smell, potential ozone damage in production, etc.). Providing very specific concerns left the potential to miss important issues that can now be identified via future research guided by results from this paper. Production was also not defined, but processing was defined as "making of products from hemp."

In addition to understanding concerns related to hemp production and processing, the authors also wanted to gauge the respondent's awareness of the term hemp. Respondents were asked to classify what they think applies when they hear the term hemp. This included responses such as marijuana, CBD oil, fiber, food, and a variety of other products. Respondents were also allowed to choose they had never heard of hemp. Using these responses, a three-category hemp awareness variable was developed. Those that were not aware of hemp selected "never heard of" as their response. Respondents that thought hemp is the same as marijuana chose that hemp is either recreational marijuana or medical marijuana. Respondents who correctly identified hemp chose other options that included CBD oil and various products made from hemp. Only $44 \%$ of respondents were aware of hemp and indicated that it is not marijuana. An additional $44 \%$ of respondents thought hemp is marijuana, while $12 \%$ had not heard of the term hemp.

After answering the hemp-based questions, respondents were asked to provide demographics (e.g., age, household income, education level, race, etc.) and zip code of their primary residence. The zip codes were then merged with zip code characteristics from the American Community Survey (United States Census Bureau, 2019a) in order to put community-level demographics with each survey respondent. The zip code-level variables included the percentage of males, percentage of different races, education level, median household income, median age, and percentage of persons employed within agriculture with the specific zip code area. Population density and the change in population density between 2012 and 2017 within each zip code were also ascertained. Though similar in nature, using the combination of individual level (i.e., individual-level demographics) and geographic level (i.e., zip code-level data) allows for control of characteristics unique to the individual as well as for controlling of community characteristics. Rather than including state fixed effects, three categories of production levels were specified. The highest level of production occurs in Kentucky, Tennessee, and North Carolina, where over 10,000 acres were reported as planted in 2019. South Carolina and Alabama represent small-scale production with less than 10,000 planted acres. No production is represented by Florida, Georgia, Louisiana, and Mississippi. A total of 2,505 surveys were collected and after eliminating incomplete responses, notably lack of zip codes, 2,108 surveys were utilized in the analysis.

Overall, the sample was representative of the Southeast on several characteristics (Table 1). Survey respondents had a lower median household income $(\$ 37,500)$ compared to the census estimates for the Southeast $(\$ 53,065)$ (United States Census Bureau, 2019b). However, the sample's median age was 42 , which is slightly higher than the census estimates of 38 (United States Census Bureau, 2019c). Eliminating persons under 18 years of age from the census estimates would move the sample in-line with the Southeast region. With respect to race, the sample is made up of $69 \%$ Caucasian (non-Hispanic or Latino), 22\% African American, and 3\% Hispanic/Latino. These demographics are in-line with Census estimates for the Southeast region, 66\% Caucasian (non-Hispanic or Latino), 25\% African American, and 8\% Hispanic/Latino. The overall zip code characteristics from respondents are summarized in Table 2. As with any survey, the results are only generalizable to populations outside the sample if the sample is representative to the population of interest. Though our sample appears to be representative across several parameters (e.g., age, race, etc.), there are other parameters that are less representative (i.e., household income). 
Table 1. Descriptive statistics of survey respondents' demographics

\begin{tabular}{|c|c|c|}
\hline Variable & Mean & Std. Dev. \\
\hline \multicolumn{3}{|l|}{ State } \\
\hline Alabama & $10 \%$ & - \\
\hline Florida & $11 \%$ & - \\
\hline Georgia & $20 \%$ & - \\
\hline Kentucky & $9 \%$ & - \\
\hline Louisiana & $9 \%$ & - \\
\hline Mississippi & $9 \%$ & - \\
\hline North Carolina & $10 \%$ & - \\
\hline South Carolina & $11 \%$ & - \\
\hline Tennessee & $11 \%$ & - \\
\hline \multicolumn{3}{|l|}{ Production } \\
\hline Large scale ( $>10,000$ acres) & $31 \%$ & - \\
\hline Small scale $(<10,000$ acres $)$ & $21 \%$ & - \\
\hline No production & $48 \%$ & - \\
\hline Percent male & $38 \%$ & - \\
\hline Age (mean in years) & 45 & 17 \\
\hline Age (median in years) & 42 & - \\
\hline \multicolumn{3}{|l|}{ Generation } \\
\hline Baby boomer or older & $37 \%$ & - \\
\hline Gen X & $39 \%$ & - \\
\hline Millennial or younger & $24 \%$ & - \\
\hline \multicolumn{3}{|l|}{ Race } \\
\hline Caucasian & $69 \%$ & - \\
\hline Hispanic or Latino & $3 \%$ & - \\
\hline African American & $22 \%$ & - \\
\hline Other race & $5 \%$ & - \\
\hline \multicolumn{3}{|l|}{ Political Affiliation } \\
\hline Democrat & $33 \%$ & - \\
\hline Republican & $34 \%$ & - \\
\hline Other party or independent & $33 \%$ & - \\
\hline \multicolumn{3}{|l|}{ Education } \\
\hline High school or less & $32 \%$ & - \\
\hline Some college or associate's degree & $36 \%$ & - \\
\hline Bachelors & $20 \%$ & - \\
\hline Graduate degree & $13 \%$ & - \\
\hline Number of adults in household & 2.1 & 1.0 \\
\hline
\end{tabular}


Table 1. (Continued)

\begin{tabular}{lcc}
\hline Variable & Mean & Std. Dev. \\
\hline Number of children in household & 0.8 & 1.2 \\
\hdashline Household income (mean in dollars) & $\$ 55,379$ & $\$ 44,976$ \\
\hline Household income (median in dollars) & $\$ 37,500$ & - \\
\hline Hemp awareness & & $12 \%$ \\
\hline Not aware of correct definition & $44 \%$ & $44 \%$ \\
\hline Hemp = marijuana & 2,108 & \\
\hline Hemp is not marijuana & & \\
\hline Number of observations &
\end{tabular}

Table 2. Descriptive statistics of survey respondents zip code characteristics

\begin{tabular}{|c|c|c|}
\hline Variable & Mean & Std. Dev. \\
\hline Percent male & $49 \%$ & - \\
\hline Median age & 38.8 & - \\
\hline \multicolumn{3}{|l|}{ Race } \\
\hline Percent Caucasian & $45 \%$ & - \\
\hline Percent Hispanic or Latino & $3 \%$ & - \\
\hline Percent African American & $16 \%$ & - \\
\hline Percent other race & $36 \%$ & - \\
\hline Median household income & $\$ 49,187$ & - \\
\hline \multicolumn{3}{|l|}{ Education } \\
\hline Less than high school (\%) & $14 \%$ & - \\
\hline High school degree or equivalent (\%) & $25 \%$ & - \\
\hline Some college or associate's degree (\%) & $33 \%$ & - \\
\hline Bachelors or higher (\%) & $27 \%$ & - \\
\hline Work in agriculture (\%) & $1 \%$ & - \\
\hline Population density (per square mile) & $1,268.77$ & $1,897.17$ \\
\hline Change in population density (2012-2017) (\%) & 73.0 & 224.4 \\
\hline
\end{tabular}

The central focus of this paper was to understand the magnitude of concern associated with living near a hemp production or processing facility. We assessed concern using a 0-100 scale where $0=$ no concern, $50=$ somewhat concerned, $100=$ extremely concerned, or respondents could mark anywhere in between. The respondent concern could be due to a plethora of perceived issues, both accurate and inaccurate. Using the 100-point scale, respondents could better indicate their concern level compared to a simple yes/no question. However, this presents a censoring of the data at the two extreme points ( 0 and 100). Utilizing ordinary least squares (OLS) in this case results in biased and inconsistent parameter estimates. Thus, the two-limit Tobit model developed by Rossett and Nelson (1975) was used. The model can be represented as: 


$$
\begin{aligned}
& y_{i}^{*}=\beta^{\prime} x_{i}+\varepsilon_{i}(i=1, \ldots, n) \\
& y_{i}= \begin{cases}0 & \text { if } y_{i}^{*} \leq 0 \\
y_{i}^{*} & \text { if } 0<y_{i}^{*}<100 \quad(i=1, \ldots, n) \\
100 & \text { if } y_{i}^{*} \geq 100\end{cases}
\end{aligned}
$$

where $y_{i}^{*}$ is a latent variable not observed for values below 0 and above 100 on the scale, $x$ is a matrix of explanatory variables, $\beta$ is a vector of coefficients, and $\epsilon$ is an independently and normally distributed error term with zero mean and variance $\sigma^{2}$. Davidson and McKinnon (1993, p. 541) note that the likelihood function in Equation (2) can be maximized to obtain coefficient estimates:

$$
\begin{aligned}
& \sum_{y_{t}^{L} \leq y_{t}^{*} \leq y_{t}^{U}} \log \left\{\frac{1}{\sigma} \emptyset\left[\frac{1}{\sigma}\left(y_{t}-x_{t} \beta\right)\right]\right\}+\sum_{y_{t}^{*}<y_{t}^{L}} \log \left\{\phi\left[\frac{1}{\sigma}\left(y_{t}^{L}-x_{t} \beta\right)\right]\right\} \\
& +\sum_{y_{t}^{*}>y_{t}^{U}} \log \left\{\phi\left[-\frac{1}{\sigma}\left(y_{t}^{U}-x_{t} \beta\right)\right]\right\}
\end{aligned}
$$

whereby the first term corresponds to the non-limit observations, term two the lower limit $y_{t}^{L}$ observations, and term three the upper limit $y_{t}^{U}$ observations. However, the estimated $\beta$-coefficients are not interpretable as the marginal effect of a unit change in an independent variable (Gould, Saupe, and Klemme, 1989). An extension of the McDonald and Moffitt decomposition for two-limit censoring to obtain the unconditional and conditional marginal effects and the corresponding probabilities of being uncensored (McDonald and Moffitt, 1980) was used.

With respect to the issues driving concern levels, we asked respondents to check the issues driving their concern from a predefined list (i.e., impact on the air, impact on water, impact on the environment, public scrutiny, the potential for illegal activity, overall safety, and other). Concerns across perceptions of hemp (i.e., not aware of the correct definition of hemp, hemp = marijuana, hemp is not marijuana) were visually compared to determine if the type of concern varied if a respondent understood that hemp is not marijuana. Next, histograms were used in order to better understand how the varying issues driving concern changed as concern level increased.

\section{Results and Discussion}

Examining the level of concern that respondents indicated shows they were "somewhat concerned" about both a production and a processing facility locating in their area (Table 3). Respondents had a mean rating of 40.5 and 42.6 on the 100-point concern scale for production and processing, respectively. Approximately $11 \%$ and $10 \%$ of the sample had no concern $(0$ on the rating scale) for hemp production or processing, respectively; and $6 \%$ and $7 \%$ were extremely concerned (100 on the rating scale) about hemp production and processing, respectively.

\subsection{Tobit Results: Production Only}

Conditional and unconditional marginal effects estimated from the Tobit model are presented in Table 4 (individual-level demographics and hemp awareness) and in Table 5 (zip code characteristics). Given the censored nature of the data, this study focuses the discussion on the conditional results. There were no differences between large-scale or small-scale production relative to states that had no production activity. This result is somewhat surprising as states are in various stages of establishing production and processing, yet Kentucky is generally viewed as the leading state in hemp production with 60,000 licensed acres in this region and 26,500 planted acres in 2019 (Table 4). Thus respondents in states where no production activity is occurring (such as Georgia), have the same level of concern for hemp production. Further, respondents that 
Table 3. Respondents level of concern for living near a hemp production or processing facility

\begin{tabular}{ccccc}
\hline & Mean & Std. Dev. & $\begin{array}{c}\text { Percent no concern } \\
\text { (0 on scale) }\end{array}$ & $\begin{array}{c}\text { Percent extremely } \\
\text { concerned (100 on scale) }\end{array}$ \\
\hline Production only & $40.5^{\mathrm{a}}$ & 32.8 & $11 \%$ & $6 \%$ \\
\hline Processing only & $42.6^{\mathrm{a}}$ & 33.1 & $10 \%$ & $7 \%$ \\
\hline
\end{tabular}

${ }^{a}$ Average responses of concern are significantly different using a pairwise $t$-test, where participants could respond on a range from $0=$ no concern to $100=$ extremely concerned.

identified as Republicans are $4.779 \%$ (given a 100-point scale) more concerned than Democrats. This result implies that firms thinking of establishing hemp production may need to consider local community support, especially in largely Republican areas.

Education also influences concern as both less educated (high school or less) and higher educated (graduate degree) respondents are more concerned about hemp production in their area than respondents with a bachelors' degree (Table 4). Respondents with a high school or less level of education had a 3.750\% higher level of concern while respondents with a graduate degree had a $3.199 \%$ higher level of concern compared to those with a bachelors' degree. With respect to other household characteristics, as the number of children in the household increased by one-unit from the mean, respondent's concern level increased by $1.062 \%$. Further, an increasing household income $(\$ 10,000$ increase from the mean) caused respondent's concern to increase by $0.332 \%$.

Examining the role of zip code characteristics and hemp awareness, areas with an increasing Hispanic/Latino population had ratings that were $25.090 \%$ higher for each $1 \%$ increase in the percentage of Hispanic/Latino populations and a decrease in the percentage of Caucasian residents (Table 5). Respondents that were not aware of the correct definition for hemp had a 3.099\% lower rating than respondents that correctly knew hemp and marijuana are not the same product. However, there was no statistically significant difference in concern between respondents that thought hemp was marijuana and respondents that knew they were not the same (Table 4).

\subsection{Tobit Results: Processing Only}

Concerns about nearby hemp processing are similar to those from the production concern model. Notably, there were again no differences in areas with large or small-scale production relative to no production activities (Table 6). Republicans had a $4.932 \%$ higher level of concern than Democrats and respondents with less (high school or less) and higher (graduate degree) education are more concerned about hemp processing in their area than respondents with a bachelors' degree. Respondents with a high school or less level of education had a $4.073 \%$ higher level of concern while respondents with a graduate degree had a $1.772 \%$ higher level of concern compared to those with a bachelors' degree. For each child above the mean, a respondent was $0.833 \%$ more concerned while for each $\$ 10,000$ increase in household income from the mean the respondent had a $0.292 \%$ higher concern level.

With respect to zip code characteristics (Table 7) and hemp awareness (Table 6), Hispanic/Latino population areas had more concern than areas with less Hispanic/Latino population. For a given area, a $25.574 \%$ higher rating for hemp processing concern resulted from every $1 \%$ increase in the Hispanic/ Latino population and with a decrease in the Caucasian population. Hemp awareness played a role in a respondent's concern level as respondents that were not aware of hemp rated their concern as $3.233 \%$ lower than respondents that were aware and correctly knew hemp is not marijuana. 
Table 4. Marginal effects of the Tobit model individual-level explanatory variables on the concern about living near hemp production

\begin{tabular}{|c|c|c|c|c|c|c|}
\hline & \multicolumn{6}{|c|}{ Marginal effects } \\
\hline & \multicolumn{2}{|c|}{$\begin{array}{l}\text { Probability of being } \\
\text { uncensored }^{\mathrm{a}}\end{array}$} & \multicolumn{2}{|c|}{$\begin{array}{l}\text { Conditional on } \\
\text { being uncensored }\end{array}$} & \multicolumn{2}{|c|}{$\begin{array}{c}\text { Unconditional value } \\
\text { of dependent } \\
\text { variable }^{c}\end{array}$} \\
\hline & $d y / d x$ & $P$ value & $d y / d x$ & $P$ value & $d y / d x$ & $P$ value \\
\hline \multicolumn{7}{|l|}{ Production } \\
\hline Large scale (>10 k acres) & -0.005 & 0.464 & -0.712 & 0.463 & -1.220 & 0.463 \\
\hline Small scale ( $<10 \mathrm{k}$ acres) & -0.005 & 0.486 & -0.717 & 0.486 & -1.227 & 0.486 \\
\hline \multicolumn{7}{|l|}{ Generation } \\
\hline Gen X & 0.002 & 0.726 & 0.366 & 0.723 & 0.628 & 0.723 \\
\hline Millennial or younger & -0.009 & 0.251 & -1.225 & 0.260 & -2.098 & 0.260 \\
\hline \multicolumn{7}{|l|}{ Race } \\
\hline Hispanic or Latino & 0.002 & 0.735 & 0.746 & 0.700 & 1.283 & 0.700 \\
\hline African American & -0.002 & 0.799 & -0.717 & 0.791 & -1.233 & 0.791 \\
\hline Other race & -0.029 & 0.000 & -4.767 & 0.008 & -8.180 & 0.008 \\
\hline \multicolumn{7}{|l|}{ Political Affiliation } \\
\hline Republican & 0.032 & 0.000 & 4.779 & 0.000 & 8.190 & 0.000 \\
\hline Other party/indep. & 0.013 & 0.138 & 1.421 & 0.137 & 2.428 & 0.137 \\
\hline \multicolumn{7}{|l|}{ Education } \\
\hline High school or less & 0.025 & 0.001 & 3.750 & 0.008 & 6.430 & 0.007 \\
\hline Some college or Associate's degree & 0.000 & 0.988 & 0.016 & 0.988 & 0.027 & 0.988 \\
\hline Graduate degree & 0.022 & 0.001 & 3.199 & 0.001 & 5.484 & 0.001 \\
\hline Number of adults in household & -0.002 & 0.494 & -0.257 & 0.493 & -0.440 & 0.493 \\
\hline Number of children in household & 0.008 & 0.003 & 1.062 & 0.002 & 1.818 & 0.002 \\
\hline Household income (in dollars) ${ }^{d}$ & 0.002 & 0.001 & 0.332 & 0.001 & 0.569 & 0.001 \\
\hline \multicolumn{7}{|l|}{ Hemp Awareness } \\
\hline Not aware of definition & -0.024 & 0.004 & -3.099 & 0.014 & -5.308 & 0.014 \\
\hline Hemp is marijuana & 0.002 & 0.815 & 0.301 & 0.810 & 0.518 & 0.810 \\
\hline Observations & \multicolumn{6}{|c|}{2108} \\
\hline LR chi-square & \multicolumn{6}{|c|}{167.3} \\
\hline Prob. $>$ chi-square & \multicolumn{6}{|c|}{0.000} \\
\hline Log likelihood & \multicolumn{6}{|c|}{-9198.2} \\
\hline Pseudo $R^{2}$ & \multicolumn{6}{|c|}{0.009} \\
\hline
\end{tabular}

aProbability of being uncensored is the marginal effects probabilities from the Tobit model for being uncensored.

${ }^{b}$ Conditional on being uncensored is the marginal effect from the Tobit model of the expected value of the dependent variable conditional on being uncensored.

'Unconditional value of dependent variable is the marginal effect from the Tobit model of the unconditional expected value of the dependent variable.

${ }^{\mathrm{d}}$ Household income is for a $\$ 10,000$ change in income level.

Bold numbers represent a variable with a statistical significance of $P>0.1$. 
Table 5. Marginal effects of the Tobit model zip code-level explanatory variables on the concern about living near hemp production

\begin{tabular}{|c|c|c|c|c|c|c|}
\hline & \multicolumn{6}{|c|}{ Marginal effects } \\
\hline & \multicolumn{2}{|c|}{$\begin{array}{l}\text { Probability of } \\
\text { being uncensored }\end{array}$} & \multicolumn{2}{|c|}{$\begin{array}{l}\text { Conditional on } \\
\text { being uncensored }\end{array}$} & \multicolumn{2}{|c|}{$\begin{array}{c}\text { Unconditional value } \\
\text { of dependent } \\
\text { variable }\end{array}$} \\
\hline & $d y / d x$ & $P$ value & $d y / d x$ & $P$ value & $d y / d x$ & $P$ value \\
\hline \multicolumn{7}{|l|}{ Zip code characteristics } \\
\hline Percent male & 0.093 & 0.411 & 13.035 & 0.410 & 22.328 & 0.410 \\
\hline Age (in years) & -0.001 & 0.548 & -0.070 & 0.548 & -0.120 & 0.548 \\
\hline \multicolumn{7}{|l|}{ Race } \\
\hline Percent Hispanic or Latino & 0.179 & 0.001 & 25.090 & 0.001 & 42.978 & 0.000 \\
\hline Percent African American & 0.016 & 0.820 & 2.265 & 0.820 & 3.879 & 0.820 \\
\hline Percent other race & -0.049 & 0.476 & -6.900 & 0.475 & -11.820 & 0.475 \\
\hline \multicolumn{7}{|l|}{ Education } \\
\hline Less than high school (\%) & 0.006 & 0.901 & 0.862 & 0.901 & 1.477 & 0.901 \\
\hline High school degree or equivalent (\%) & 0.002 & 0.981 & 0.215 & 0.981 & 0.368 & 0.981 \\
\hline Some college or Associate's degree (\%) & -0.041 & 0.355 & -5.689 & 0.354 & -9.746 & 0.354 \\
\hline Median household income ${ }^{a}$ & -0.001 & 0.743 & -0.000 & 0.743 & -0.000 & 0.743 \\
\hline Work in agriculture (\%) & 0.092 & 0.546 & 12.809 & 0.546 & 21.941 & 0.546 \\
\hline Population density & -0.000 & 0.345 & -0.000 & 0.344 & -0.001 & 0.344 \\
\hline Change in population density (2012-2017) & -0.000 & 0.446 & -0.002 & 0.446 & -0.003 & 0.446 \\
\hline Observations & \multicolumn{6}{|c|}{2108} \\
\hline LR chi-square & \multicolumn{6}{|c|}{167.3} \\
\hline Prob. $>$ chi-square & \multicolumn{6}{|c|}{0.000} \\
\hline Log likelihood & \multicolumn{6}{|c|}{-9198.2} \\
\hline Pseudo $R^{2}$ & \multicolumn{6}{|c|}{0.009} \\
\hline
\end{tabular}

aprobability of being uncensored is the marginal effects probabilities from the Tobit model for being uncensored.

${ }^{b}$ Conditional on being uncensored is the marginal effect from the Tobit model of the expected value of the dependent variable conditional on being uncensored.

'Unconditional value of dependent variable is the marginal effect from the Tobit model of the unconditional expected value of the dependent variable.

Bold numbers represent a variable with a statistical significance of $P>0.1$.

\subsection{Examination of Externalities by Awareness Level}

As noted above, there are concerns by a majority of respondents for both production and processing locating near them. Though not the primary focus of this study, a cursory examination of the reasons for concern is explored (Table 8 ). The potential for illegal activity was noted by $43 \%$ of the respondents as a concern for production followed by overall safety (33\%) and the impact on the air (32\%). Similarly, $41 \%$ of respondents indicated illegal activity as a concern for processing while overall safety (32\%) and impact on the environment $(31 \%)$ are also a significant concern. However, each of the externalities listed was a concern for around $30 \%$ of respondents for production and processing.

When evaluating externalities for hemp awareness the overall safety associated with hemp production is an issue for $46 \%$ of respondents that were not aware of the correct definition for hemp, 
Table 6. Marginal effects of the Tobit model individual-level explanatory variables on the concern about living near a hemp processing facility

\begin{tabular}{|c|c|c|c|c|c|c|}
\hline & \multicolumn{6}{|c|}{ Marginal effects } \\
\hline & \multicolumn{2}{|c|}{$\begin{array}{l}\text { Probability of being } \\
\text { uncensored }^{\mathrm{a}}\end{array}$} & \multicolumn{2}{|c|}{$\begin{array}{l}\text { Conditional on } \\
\text { being uncensored }\end{array}$} & \multicolumn{2}{|c|}{$\begin{array}{c}\text { Unconditional value } \\
\text { of dependent } \\
\text { variable }^{c}\end{array}$} \\
\hline & $d y / d x$ & $P$ value & $d y / d x$ & $P$ value & $d y / d x$ & $P$ value \\
\hline \multicolumn{7}{|l|}{ Production } \\
\hline Large scale ( $>10 \mathrm{k}$ acres) & -0.000 & 0.941 & -0.072 & 0.941 & -0.125 & 0.941 \\
\hline Small scale ( $<10 \mathrm{k}$ acres) & -0.004 & 0.524 & -0.658 & 0.523 & -1.144 & 0.523 \\
\hline \multicolumn{7}{|l|}{ Generation } \\
\hline Gen X & 0.003 & 0.528 & 0.670 & 0.516 & 1.166 & 0.516 \\
\hline Millennial or younger & -0.004 & 0.570 & -0.610 & 0.575 & -1.061 & 0.575 \\
\hline \multicolumn{7}{|l|}{ Race } \\
\hline Hispanic or Latino & 0.001 & 0.763 & 0.871 & 0.651 & 1.520 & 0.651 \\
\hline African American & -0.005 & 0.583 & -1.740 & 0.517 & -3.033 & 0.517 \\
\hline Other race & -0.019 & 0.000 & -4.271 & 0.017 & -7.437 & 0.017 \\
\hline \multicolumn{7}{|l|}{ Political Affiliation } \\
\hline Republican & 0.025 & 0.000 & 4.932 & 0.000 & 8.580 & 0.000 \\
\hline Other party/indep. & 0.011 & 0.118 & 1.512 & 0.116 & 2.624 & 0.116 \\
\hline \multicolumn{7}{|l|}{ Education } \\
\hline High school or less & 0.017 & 0.000 & 4.073 & 0.004 & 7.094 & 0.004 \\
\hline Some college or Associate's degree & 0.001 & 0.862 & 0.186 & 0.863 & 0.324 & 0.863 \\
\hline Graduate degree & 0.010 & 0.058 & 1.772 & 0.059 & 3.083 & 0.058 \\
\hline Number of adults in household & -0.001 & 0.739 & -0.126 & 0.739 & -0.218 & 0.739 \\
\hline Number of children in household & 0.005 & 0.020 & 0.833 & 0.017 & 1.448 & 0.017 \\
\hline Household income (in dollars) ${ }^{\mathrm{a}}$ & 0.002 & 0.004 & 0.292 & 0.003 & 0.508 & 0.003 \\
\hline \multicolumn{7}{|l|}{ Hemp Awareness } \\
\hline Not aware of definition & -0.018 & 0.002 & -3.233 & 0.010 & -5.624 & 0.010 \\
\hline Hemp is marijuana & -0.001 & 0.864 & -0.210 & 0.867 & -0.366 & 0.867 \\
\hline Observations & \multicolumn{6}{|c|}{2108} \\
\hline LR chi-square & \multicolumn{6}{|c|}{144.5} \\
\hline Prob. $>$ chi-square & \multicolumn{6}{|c|}{0.000} \\
\hline Log likelihood & \multicolumn{6}{|c|}{-9282.9} \\
\hline Pseudo $R^{2}$ & \multicolumn{6}{|c|}{0.008} \\
\hline
\end{tabular}

aProbability of being uncensored is the marginal effects probabilities from the Tobit model for being uncensored.

${ }^{b}$ Conditional on being uncensored is the marginal effect from the Tobit model of the expected value of the dependent variable conditional on being uncensored.

'Unconditional value of dependent variable is the marginal effect from the Tobit model of the unconditional expected value of the dependent variable.

${ }^{\mathrm{d}}$ Household income is for a $\$ 10,000$ change from the average income level.

Bold numbers represent a variable with a statistical significance of $P>0.1$. 
Table 7. Marginal effects of the Tobit model zip code-level explanatory variables on the concern about living near a hemp processing facility

\begin{tabular}{|c|c|c|c|c|c|c|}
\hline & \multicolumn{6}{|c|}{ Marginal effects } \\
\hline & \multicolumn{2}{|c|}{$\begin{array}{l}\text { Probability of } \\
\text { being uncensored }\end{array}$} & \multicolumn{2}{|c|}{$\begin{array}{l}\text { Conditional on } \\
\text { being uncensored }\end{array}$} & \multicolumn{2}{|c|}{$\begin{array}{l}\text { Unconditional } \\
\text { value of } \\
\text { dependent } \\
\text { variable }^{c}\end{array}$} \\
\hline & $d y / d x$ & $P$ value & $d y / d x$ & $P$ value & $d y / d x$ & $P$ value \\
\hline \multicolumn{7}{|l|}{ Zip code characteristics } \\
\hline Percent male & 0.088 & 0.311 & 16.175 & 0.308 & 28.131 & 0.308 \\
\hline Age (in years) & -0.000 & 0.788 & -0.031 & 0.788 & -0.055 & 0.788 \\
\hline \multicolumn{7}{|l|}{ Race } \\
\hline Percent Hispanic or Latino & 0.140 & 0.001 & 25.574 & 0.000 & 44.476 & 0.000 \\
\hline Percent African American & 0.049 & 0.375 & 8.883 & 0.373 & 15.448 & 0.373 \\
\hline Percent other race & -0.029 & 0.586 & -5.283 & 0.586 & -9.187 & 0.586 \\
\hline \multicolumn{7}{|l|}{ Education } \\
\hline Less than high school (\%) & 0.027 & 0.472 & 5.029 & 0.471 & 8.746 & 0.471 \\
\hline High school degree or equivalent (\%) & -0.011 & 0.822 & -1.987 & 0.822 & -3.456 & 0.822 \\
\hline Some college or Associate's degree (\%) & -0.020 & 0.563 & -3.569 & 0.562 & -6.207 & 0.562 \\
\hline Median household income ${ }^{a}$ & 0.000 & 0.934 & 0.000 & 0.934 & 0.000 & 0.934 \\
\hline Work in agriculture (\%) & 0.074 & 0.523 & 13.610 & 0.523 & 23.670 & 0.523 \\
\hline Population density & -0.000 & 0.539 & -0.000 & 0.538 & -0.000 & 0.538 \\
\hline Change in population density $(2012-2017)$ & -0.000 & 0.429 & -0.002 & 0.428 & -0.003 & 0.428 \\
\hline Observations & \multicolumn{6}{|c|}{2108} \\
\hline LR chi-square & \multicolumn{6}{|c|}{144.5} \\
\hline Prob. > chi-square & \multicolumn{6}{|c|}{0.000} \\
\hline Log likelihood & \multicolumn{6}{|c|}{-9282.9} \\
\hline Pseudo $R^{2}$ & \multicolumn{6}{|c|}{0.008} \\
\hline
\end{tabular}

aProbability of being uncensored is the marginal effects probabilities from the Tobit model for being uncensored.

${ }^{b}$ Conditional on being uncensored is the marginal effect from the Tobit model of the expected value of the dependent variable conditional on being uncensored.

'Unconditional value of dependent variable is the marginal effect from the Tobit model of the unconditional expected value of the dependent variable.

Bold numbers represent a variable with a statistical significance of $P>0.1$.
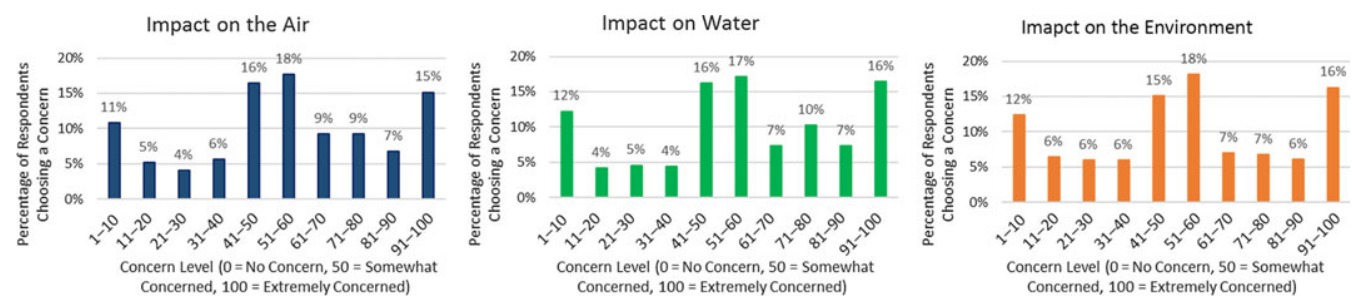

Figure 1. Percentage of respondents concerned about varying environmental issues by their level of concern for hemp production. 
Table 8. Respondents reported concern for living near production or processing by their awareness of the definition of Hemp

\begin{tabular}{|c|c|c|c|c|}
\hline & $\begin{array}{l}\text { Not aware of the correct } \\
\text { definition for hemp }\end{array}$ & $\begin{array}{l}\text { Believe that hemp is the } \\
\text { same as marijuana }\end{array}$ & $\begin{array}{l}\text { Are aware of the correct } \\
\text { definition for hemp }\end{array}$ & Total \\
\hline \multicolumn{5}{|l|}{ Hemp production } \\
\hline Public scrutiny & $20 \%$ & $32 \%$ & $29 \%$ & $29 \%$ \\
\hline $\begin{array}{l}\text { Impact on the } \\
\text { air }\end{array}$ & $30 \%$ & $34 \%$ & $31 \%$ & $32 \%$ \\
\hline Impact on water & $28 \%$ & $30 \%$ & $26 \%$ & $28 \%$ \\
\hline $\begin{array}{l}\text { Impact on } \\
\text { environment }\end{array}$ & $29 \%$ & $35 \%$ & $25 \%$ & $30 \%$ \\
\hline $\begin{array}{l}\text { Potential for } \\
\text { illegal } \\
\text { activities }\end{array}$ & $36 \%$ & $52 \%$ & $36 \%$ & $43 \%$ \\
\hline Overall safety & $46 \%$ & $35 \%$ & $27 \%$ & $33 \%$ \\
\hline Other & $5 \%$ & $8 \%$ & $8 \%$ & $7 \%$ \\
\hline \multicolumn{5}{|l|}{ Hemp processing } \\
\hline Public scrutiny & $18 \%$ & $29 \%$ & $26 \%$ & $27 \%$ \\
\hline $\begin{array}{l}\text { Impact on the } \\
\text { air }\end{array}$ & $32 \%$ & $32 \%$ & $25 \%$ & $29 \%$ \\
\hline Impact on water & $27 \%$ & $32 \%$ & $28 \%$ & $29 \%$ \\
\hline $\begin{array}{l}\text { Impact on } \\
\text { environment }\end{array}$ & $32 \%$ & $34 \%$ & $28 \%$ & $31 \%$ \\
\hline $\begin{array}{l}\text { Potential for } \\
\text { illegal } \\
\text { activities }\end{array}$ & $33 \%$ & $48 \%$ & $35 \%$ & $41 \%$ \\
\hline Overall safety & $43 \%$ & $34 \%$ & $26 \%$ & $32 \%$ \\
\hline Other & $5 \%$ & $7 \%$ & $9 \%$ & $8 \%$ \\
\hline
\end{tabular}
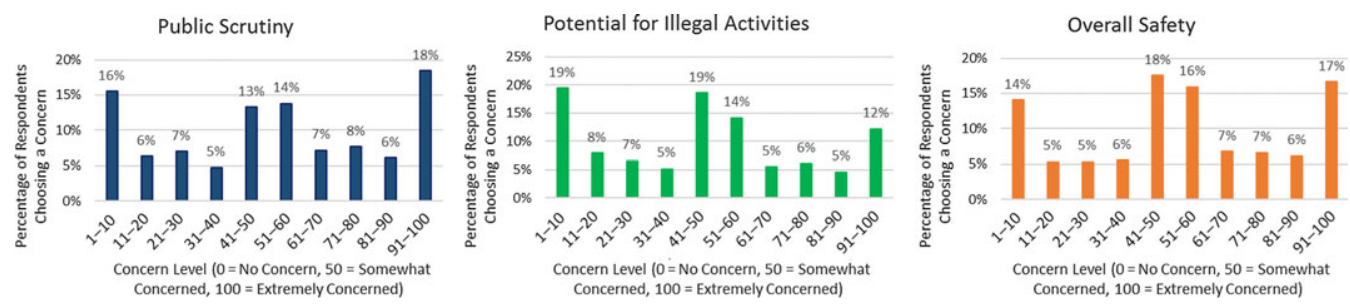

Figure 2. Percentage of respondents concerned about varying social issues by their level of concern for hemp production.

while only an issue for $35 \%$ of those that believe hemp is marijuana. The least concerned respondents over safety are those that correctly define hemp as not marijuana, where only $27 \%$ of respondents indicated this issue (Table 6). The hemp processing results follow a similar pattern. Public scrutiny is an issue for only $20 \%$ and $18 \%$ of non-aware hemp respondents for production and processing, respectively. 

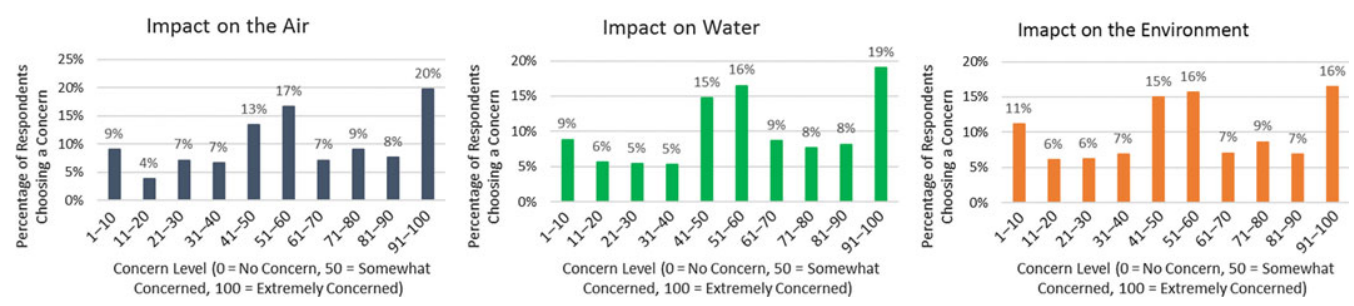

Figure 3. Percentage of respondents concerned about varying environmental issues by their level of concern for hemp processing.
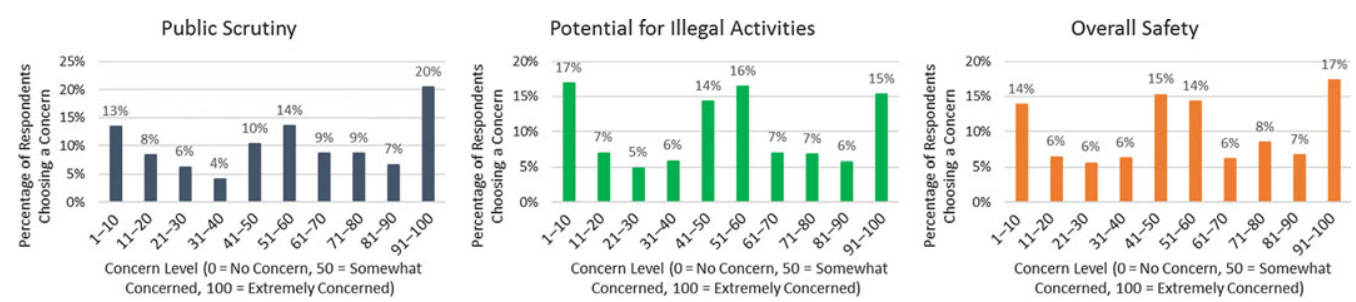

Figure 4. Percentage of respondents concerned about varying social issues by their level of concern for hemp processing.

\subsection{Examination of Externalities by Concern Level}

When examining the production externality results over varying concern levels, the results are multimodal across many of the production externalities. As shown in Figure 1, the environmental externalities, air and water are skewed to the right. This implies that as concern level increases, the percentage of respondents choosing an impact on air as a concern increased. At the 1-10, 11-20, 21-30, and 31-40 concern level, 11\%, 5\%, 4\%, and $6 \%$ of respondents that selected impact on air were in these concern levels, respectively. However, at the 61-70, 71-80, 81-90, and 90-100 concern levels, $9 \%, 9 \%, 7 \%$, and $15 \%$ of respondents that selected impact on air were in these concern levels, respectively. Similar percentages can be found for impact on water. On the other hand, the impact on the environment did not have increased percentages as the level of concern increased.

With respect to social issue concerns for the production of hemp, the potential for illegal activity is skewed to the left (Figure 2). Respondents that were less concerned about living near production were more likely to perceive the potential for illegal activity as a concern. This is in contrast to the impact of air and water.

In evaluating the externalities associated with processing, the impact of air, water, and environment were skewed to the right (Figure 3). This implies that as concern increases, a higher percentage of respondents chose these externalities at a higher rate than respondents at lower concern levels. Public scrutiny was similarly skewed to the right (Figure 4). However, the potential for illegal activity and overall safety saw similar percentages both above and below the middle categories.

\section{Conclusions}

As agricultural prices continue to be depressed and farm financials are struggling, producers are looking for alternative crops to increase profitability. Thus, with demand for hemp-based products (especially CBD oil) continuing to increase, many producers and cities will look to hemp to provide increased revenue; however, the profitability of hemp production continues to be highly 
variable from year to year given increasing price volatility at the farm gate. As such, producers and cities need to understand how communities will react to efforts to begin producing or expanding hemp operations. Little research has examined this issue even though the policy and business implications are critical. For instance, producers looking to begin production may face opposition from their neighbors, communities, and local government officials that fear hemp production and processing in their area. This can become particularly challenging when decisions on local ordinances are debated and permits or zoning discussions focus on externalities. Further, cities looking to allow hemp production in urban areas may also face their own issues as residents provide resistance to these endeavors.

This research provides a first look at the concerns regarding production and processing operations. Takeaways from this research can help producers and governmental officials navigate many of the issues associated with producing and processing hemp. Notably, states with large-scale production, small-scale production, and those with no production show the same level of concern. Producers and/or cities interested in the production/processing of hemp should not assume that since their area is already growing hemp that they are immune to the concerns of local residents. Producers and/or cities that want to produce/process hemp should make efforts to engage their communities in discussions to address issues/fears of residents.

Assuming that more or less educated consumers do not share concerns about hemp is a fallacy. Respondents with a high school or less education have a similar amount of concern as respondents with a graduate degree. This lends itself to the importance of targeted education about hemp and the externalities related to production/processing. In particular, this is an opportunity for Cooperative Extension to provide unbiased research-based information as to-date much readily available information is provided by industry or advocacy groups.

With respect to locating production in certain areas, high-income zip codes do not have a higher concern; however, households with higher income are more concerned likely indicating a preference for not having related activities in one's own backyard. Thus, producers looking to begin production may look toward higher-income areas, but they need to engage with their neighbors to allay any fears they may have. Educational efforts by producers, associations, and policy makers focused on stressing the differences between hemp and marijuana are also most likely destined to fail. Whether or not a respondent confused the terms hemp and marijuana had no impact on their level of concern for nearby production or processing. This is most likely due to respondents realizing externalities beyond hemp's relationship with marijuana is a major concern.

Some of these issues may be addressed in the future through breeding and developing varieties that do not have certain characteristics. For example, hemp is known to have multiple genes involved in terpene synthesis (aroma producing compounds) (Booth, Page, and Bohlmann, 2017). Breeding efforts are underway to better understand these profiles, which could potentially lead to altering levels of certain non-desirable smells for hemp production (Booth and Bohlmann, 2019; Mediavilla and Steinemann, 1997). However, the relationships between phytochemical profiles are still being explored, and potential "low odor" varieties could take years to bring into marketable production.

Finally, policy makers and producers need to be aware and understand the externalities (whether real or perceived) that exist for hemp production and processing. Notably, not all respondents are worried about illegal activity or overall safety. Many respondents were concerned with environmental issues that impact the air or water. Policy makers can help address these concerns by enacting legislation/regulations that help ensure environmentally friendly best management practices. Producers can also educate consumers on their production methods. By evaluating the concerns of their neighbors and communities, producers, associations, and policy makers can facilitate a smoother entry into the production/processing of hemp. Future research should focus on the exact nature of the negative externalities, notably delving into the exact concerns 
consumers have about how hemp production/processing will impact the air, water, and other environmental and social factors relevant to a particular community.

\section{References}

Averink, J. “Global Water Footprint of Industrial Hemp Textile.” Enschede, Netherlands: University of Twente, 2015. Internet site: https://essay.utwente.nl/68219/1/Averink,\%20J.\%200198501\%20openbaar.pdf (Accessed June 18, 2019).

Booth, J.K., J.E. Page, and J. Bohlmann. “Terpene Synthases from Cannabis Sativa.” PLoS One 12,3(2017):e0173911. doi: 10. 1371/journal.pone.0173911.

Booth, J.K., and J. Bohlmann. “Terpenes in Cannabis Sativa - From Plant Genome to Humans.” Plant Science 284(2019): $67-72$.

Buckner, D. “Greenhouse Growers Turn to Cannabis to Cash in on Lucrative Crop.” CBC News, 2018. Internet site: https:// www.cbc.ca/news/business/cannabis-greenhouse-boom-1.4863171 (Accessed October 21, 2020).

Cherney, J.H. and E. Small. "Industrial Hemp in North America: Production, Politics, and Potential." Agronomy 6,4(2016):58-84.

Cordan, A. "Thieves Steal Thousands of Dollars Worth of Hemp Plants from Cheatham Co. Farmer.” WKRN.com, 2019. Internet site: https://www.wkrn.com/news/thieves-steal-thousands-of-dollars-worth-of-hemp-plants-from-cheatham-cofarmer/ (Accessed June 20, 2019).

Cui, X.I., and S.A. Smith. 2019 Industrial Hemp Extract (CBD) Production Budget (1 Acre). Knoxville, TN: University of Tennesse Extension Department of Agricultural and Resource Economics, Budget D41, 2019. Internet site: https:// extension.tennessee.edu/publications/Documents/D41.pdf (Accessed June 20, 2019).

Davidson, R. and J.G. McKinnon. Estimation and Inference in Econometrics. New York, NY: Oxford University Press, 1993.

Driscoll, K. "Wapakoneta Residents Voice Concern Over Greenhouse Lighting." Dayton Daily News, 2017. Internet site: https://www.daytondailynews.com/business/wapakoneta-residents-voice-concern-over-greenhouse-lighting/ oMD8NoukcVu8qwyY3gbqKL/ (Accessed June 16, 2019).

Eltouny, L. "Field of Drying Hemp in Bend Causes a Stink." KTVZ News, 2018. Internet site: https://www.ktvz.com/news/ field-of-drying-hemp-in-bend-causes-a-stink/833057505 (Accessed June 23, 2019).

Georgieva, K. “It's Not the Northern Lights - It's a Borealis of Greenhouse Glows.” CBC News, 2018. Internet site: https:// www.cbc.ca/news/canada/windsor/not-northern-lights-greenhouse-glows-1.4924468 (Accessed June 20, 2019).

Gould, B.W., W.E. Saupe, and R.M. Klemme. "Conservation Tillage: The Role of Farm and Operator Characteristics and the Perception of Soil Erosion.” Land Economics 65,2(1989):167-82.

Hanchar, J.J. "Economics of Producing Industrial Hemp in New York State: Costs and Returns, 2019 Budgets." Ithaca, NY: School of Integrative Plant Science, Cornell University, 2019. Internet site: http://www.hort.cornell.edu/expo/pdf/ 20190115-2-hanchar.pdf (Accessed June 20, 2019).

Heady Vermont. "Thefts Put Damper on Vermont Hemp Harvest.” Heady Vermont, September 24, 2018. Internet site: https:/headyvermont.com/2018/09/24/thefts-put-damper-on-vermont-hemp-harvest/ (Accessed June 21, 2019).

Johnson, R. Hemp as an Agricultural Commodity. Washington, DC: U.S. Congressional Research Service, CRS Report 32725, 2018.

Malone, T. and K. Gomez. "Hemp in the United States: A Case Study of Regulatory Path Dependence." Applied Economic Perspectives and Policy 41,2(2019):199-214.

McDonald, J.F. and R.A. Moffitt. “The Uses of Tobit Analysis.” Review of Economics and Statistics 62,2(1980):318-21.

Mead, A. "The Legal Status of Cannabis (Marijuana) and Cannabidiol (CBD) Under U.S. Law." Epilepsy and Behavior 70, $\mathrm{B}(2017): 288-91$.

Mediavilla V, and Steinemann S. "Essential Oil of Cannabis Sativa L. Strains." Journal of the International Hemp Association 4,2(1997):82-4.

Norwood, B., and S. Murray. FooDS: Food Demand Survey. Stillwater, OK: Oklahoma State University Department of Agricultural Economics, Volume 5, Issue 11, March 20, 2018.

Ouriel, A. "Mucci Can't Expand Until Light Problem Gets Fixed." Sandusky Register, 2019. Internet site: http://www. sanduskyregister.com/story/201901200003 (Accessed June 20, 2019).

Rossett, R.N., and F.N. Nelson. "Estimation of the Two-Limit Probit Regression Model." Econometrica 43(1975):141-6.

Roth, G., J. Harper, H. Manzo, A. Collins, and L. Kime. "Industrial Hemp Production." Penn State Extension, 2018. Internet site: https://extension.psu.edu/industrial-hemp-production (Accessed June 18, 2019).

Shepherd, J. and T. Mark. "The Economics of Hemp Production in Kentucky." University of Kentucky College of Agriculture, Food and Environment Newsletter, 2019. Internet site: https:/hemp.ca.uky.edu/sites/hemp.ca.uky.edu/files/ extbluesheetmar1920.pdf (Accessed June 22, 2019).

Shipman, M. “Is Hemp the Same Thing as Marijuana?" Phys.org, 2019. Internet site: https://phys.org/news/2019-02-hempmarijuana.html (Accessed June 20, 2019).

Skodzinski, N. "Considering Cannabis? Greenhouse Grower Magazine,” 2017. Internet site: https://www.greenhousemag. com/article/gm0715-cannabis-market-expansion-considerations/ (Accessed June 20, 2019). 
Smith-Heisters, S. "Environmental Costs of Hemp Prohibition in the United States." Journal of Industrial Hemp 13,2(2008):157-70.

Stansbury, L. “Annual Retail Sales for Hemp Products Estimated at \$820 Million.” votehemp.com, 2018. Internet site: https:// www.votehemp.com/press_releases/2017-annual-retail-sales-for-hemp-products/ (Accessed June 20, 2019).

Sterns, J.A. "Is the Emerging U.S. Hemp Industry Yet Another Boom-Bust Market for U.S. Farmers?" Choices 34,3(2019),

Tornay, K. "School Sours on Scent of Hemp." KTVL News, 2018. Internet site: https://ktvl.com/news/local/school-sours-onstench-of-hemp (Accessed June 20, 2019).

Vielkind, J. "Hemp Becomes Booming Crop for New York Farmers.” Wall Street Journal, 2019. Internet site: https://www.wsj. com/articles/hemp-becomes-booming-crop-for-new-york-farmers-11564930800 (Accessed October 21, 2020).

votehemp.com. "U.S. Hemp Crop Report," 2019. Internet site: https://www.votehemp.com/u-s-hemp-crop-report/ (Accessed October 30, 2019).

Wright, J. "ColorPoint to Transition to Full Hemp Production in Merger with AgTech Scientific." Greenhouse Grower Magazine, 2019. Internet site: https://www.greenhousegrower.com/management/colorpoint-to-transition-to-full-hempproduction-in-merger-with-agtech-scientific/ (Accessed June 20, 2019).

United States Census Bureau. “Database Search for American Factfinder," 2019a. Internet site: https://factfinder.census.gov/ faces/nav/jsf/pages/searchresults.xhtml?refresh=t (Accessed June 20, 2019).

United States Census Bureau. "Income in the Past 12 Months (in 2017 Inflation-Adjusted Dollars): 2013-2017 American Community Survey 5-Year Estimates. S1901,” 2019b. Internet site: https://factfinder.census.gov/faces/tableservices/jsf/ pages/productview.xhtml?pid=ACS_17_5YR_S1901\&prodType=table (Accessed June 20, 2019).

United States Census Bureau. “Age and Sex: 2013-2017 American Community Survey 5-Year Estimates. S0101,” 2019c. Internet site: https:/factfinder.census.gov/faces/tableservices/jsf/pages/productview.xhtml?pid=ACS_17_5YR_S0101\&prodType= table (Accessed June 20, 2019).

\section{Appendix A}

Q9 Would you have any concerns about living near a farm or production facility that grows/produces the following?

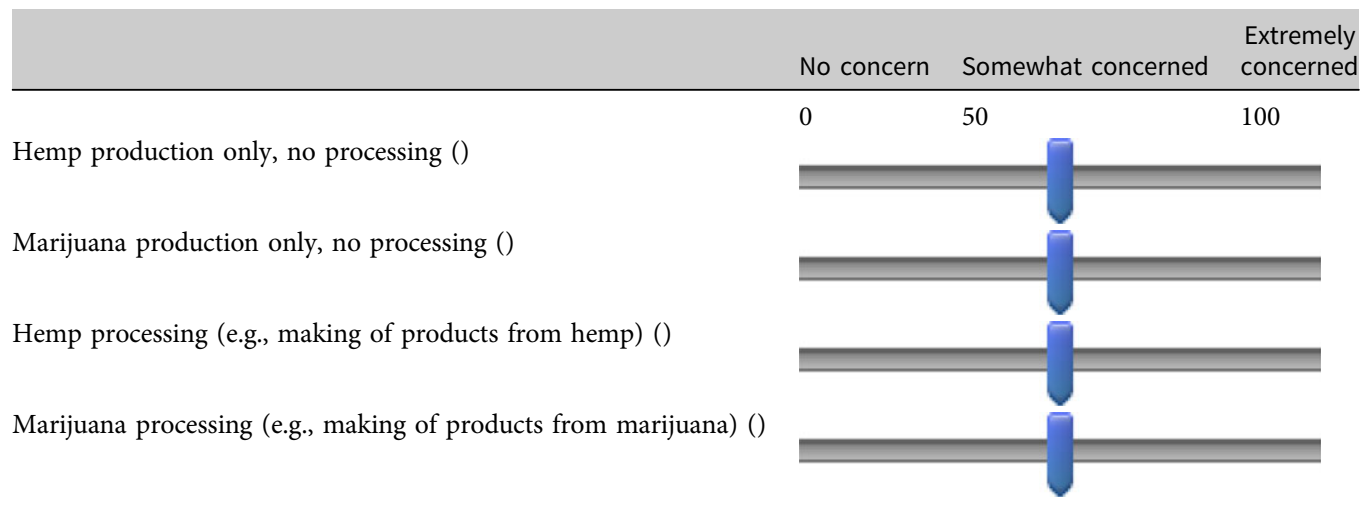

Display This Question:

If Would you have any concerns about living near a farm or production facility that grows/produces $\mathrm{t}$... (Hemp production only, no processing) $>0$

Q10 What concern would you have about living near a farm or production facility that grows hemp? (choose all that apply)

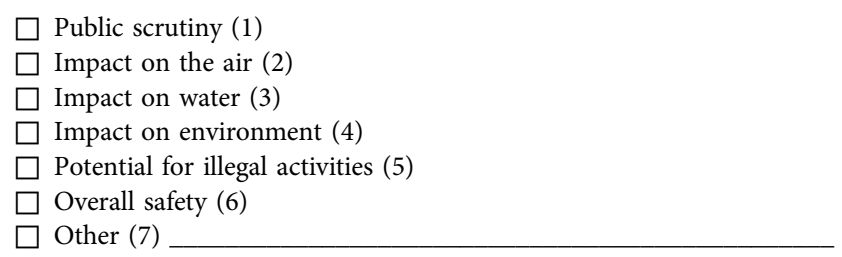

Display This Question:

If Would you have any concerns about living near a farm or production facility that grows/produces t... (Hemp processing [e.g., making of products from hemp]) $>0$ 
Q11 What concern would you have about living near a farm, production facility, or business that produces products (e.g., CBD oil, fiber, food products, etc.) made with hemp? (choose all that apply)
$\square$ Public scrutiny (1)
$\square$ Impact on the air (2)
$\square$ Impact on water (3)
$\square$ Impact on environment (4)
$\square$ Potential for illegal activities (5)
$\square$ Overall safety (6)
$\square$ Other (7)

Cite this article: Campbell JH, Rabinowitz AN, and Campbell BL (2020). Concern and Externalities Associated with Locating Hemp Production and Processing Facilities. Journal of Agricultural and Applied Economics 52, 624-641. https://doi.org/ 10.1017/aae.2020.22 